\title{
ČOVJEK, CRKVA I DRUŠTVO U PORUKAMA IVANA PAVLA II. U SPLITU I SOLINU 1998.
}

\author{
Emanuel Petrov
}

\begin{abstract}
UDK: 272-732.2Iohannes Paulus, sanctus 272-46(497.583Split)(497.583Solin)“1998“:272-732.2

Katolički bogoslovni fakultet

Sveučilišta u Splitu

Stručni članak

donepetrov@gmail.com Primljeno 02/2018.
\end{abstract}

\section{Sažetak}

O dvadesetoj obljetnici pohoda sv. Ivana Pavla II. Hrvatskoj autor analizira Papine poruke, s posebnim naglaskom na susrete u Splitu $i$ Solinu, želeći $s$ vremenskim odmakom od 20 godina naći uporište $i$ neprolazne vrijednosti za Crkvu i suvremeno hrvatsko društvo. Istine o čovjeku, Crkvi i društvu na koje Papa upozorava utemeljene su na evanđeoskoj riznici i povijesnom iskustvu te imaju neprolaznu vrijednost, a nakon dva desetljeća pozivaju na pastoralnu i društvenu inventuru. U središtu pozornosti je čovjek, njegov identitet i poslanje u Crkvi i društvu. Papa se predstavlja kao hodočasnik evanđelja, jer za njega evanđelje predstavlja divljenje nad dostojanstvom čovjeka u sujetlu objave. Tako osvijetljen identitet is njim povezano svjedočansko poslanje čovjeka, Crkve i društva usmjereni su prema izgradnji kulture života i njegova očuvanja. Čovjek je polazišna, središnja, ali i ishodišna točka evangelizacijskih i demokratizacijskih procesa. Shodno tome, imperativ današnjice je nastavak liječenja povijesnih rana, kako bi čovjek trećeg tisućljeća, nasuprot neoliberalnom kapitalizmu i konzumerizmu, mogao ostati na čurstom temelju kršćanskih vrednota te dao svoj doprinos istinskoj demokratizacija društva.

Ključne riječi: Ivan Pavao II., čovjek, hodočašće, evangelizacija, demokratizacija.

\section{UVOD}

Drugi pastirski pohod Ivana Pavla II. Hrvatskoj godine 1998. bilo je 84. apostolsko putovanje sv. Ivana Pavla II. pape kojeg su upravo zbog brojnih apostolskih putovanja prozvali Hodočasnikom Mira. Papin posjet Hrvatskoj, koji se je odvijao od 2. do 4. listopada 1998., a uključivao je posjete Zagrebu, Mariji Bistrici, Splitu i 
Solinu, dogodio se je u iznimno važnim povijesno-društvenim prilikama u kojima se je našla mlada hrvatska država i hrvatski narod. Naime, taj je pohod omeđen, s jedne strane, krajem polustoljetnog razdoblja komunističke ateizacije, a s druge završetkom Domovinskog rata kojim je izborena dugo željena nezavisnost. Pred hrvatskim narodom stajali su izazovi demokratizacije. Nove društvene prilike i nova evangelizacija nakon sustavne ateizacije tražile su od Crkve u Hrvata istinsko promicanje moralnih vrednota i socijalnog nauka te oživljavanje tradicionalne vjere, kao i uključivanje laika u njezino poslanje. Pohod Ivana Pavla II. značio je potporu na putu nepokolebljivosti u vjeri i vjernosti Kristu, njegovoj Crkvi i Petrovu nasljedniku u Rimu. ${ }^{1}$ Cijeli pohod odvijao se pod geslom „Bit ćete mi svjedoci“ (Dj 1,8), naznačujući dvije bitne dimenzije čovjeka, Crkve i društva: dostojanstvo ljudskog i kršćanskog identiteta te od njega nedjeljivo svjedočko poslanje.

Dvadesetak godina poslije Papina drugog pohoda hrvatskom narodu, Crkvi u Hrvata i svim ljudima dobre volje, Hrvatska se nalazi u posve novim društvenim prilikama. Hrvatska je u međuvremenu postala članica Europske unije, NATO saveza, članica brojnih drugih međunarodnih asocijacija i udruga te potpisnica brojnih međunarodnih ugovora i konvencija. No, nažalost, u proteklih dvadesetak godina nisu nestale brojne negativnosti iz društvenog, političkog, kulturnog i medijskog ozračja koje je dominantno u Hrvatskoj. Manjak demokracije i istinskih demokratskih procesa, povezanih s ostacima komunističke svijesti i naslijeđa, usporavaju i otežavaju izgradnju suvremenog društva utemeljenog na istinskoj demokraciji i okrenutog boljitku svih svojih građana. Ulaskom u Europsku uniju Hrvatsku je pogodilo novo zlo, naime, velik val iseljavanja, koji prijeti opustošenju cijelih krajeva, što izaziva zabrinutost i zebnju kod svih koji ljube svoj narod i svoju domovinu.

U surječju s navedenim društvenim prilikama vjerujemo kako su poruke sv. Ivana Pavla II. izrečene prije dvadeset godina i danas veoma aktualne, gotovo proročke, te kako mogu dati vrijedan poticaj za izgradnju boljega društva, dakako, uz uvjet da ih se sasluša i posluša. Papino je polazište govor o čovjeku i njegovu identitetu, a potom prelazi na pitanje izgradnje društva, odnosno poslanja Crkve.

\footnotetext{
Usp. Ante Jurić, Pozdravni govor na Žnjanu u Splitu, 4. listopada 1998., u: Ivan Pavao II., Bit ćete mi sujedoci. Govori za vrijeme pastoralnog pohoda Hrvatskoj od 2. do 4. listopada 1998., Kršćanska sadašnjost, Zagreb, 1998., 72-74, ovdje 73-74. Iz istog izdanja navedeni su i svi drugi govori izrečeni za vrijeme ovog pastirskog pohoda. U nastavku uz naslov donosimo broj stranice, budući da određeni govori nisu podijeljeni brojevima.
} 
Papa nije propustio istaknuti svijetlu ulogu kršćanskih svjedoka, posebno kardinala Stepinca, kojega je u prigodi svog drugog posjeta Hrvatskoj i proglasio blaženim.

\section{1. ČOVJEK I NJEGOVO POSLANJE}

Već na samom početku drugoga pastirskog pohoda Hrvatskoj Ivan Pavao II. se predstavio kao hodočasnik Evanđelja. „Hodočašće“ i „Evanđelje“ dva su ključna pojma, koji se nadovezuju na srž Wojtylina nauka o čovjeku. Čovjek je prije svega slika Božja (imago Dei) i kao takav tražitelj istine (homo capax veri). On ima mogućnost upravljati svojim životom i susresti Boga u zajedništvu osoba (ipsi sibi providens, homo capax Dei). ${ }^{2} \mathrm{U}$ tom kontekstu "biti hodočasnik" imalo je značiti da se papa pridružuje zajedništvu hrabrih tražitelja i svjedoka istine kroz povijest Crkve na ovim prostorima, te istovremeno želi u izazovima današnjice prednjačiti u očuvanju temeljnih vrijednosti na kojima počiva identitet čovjeka, Crkve i društva. Stoga je odmah na početku pohoda istaknuo: „Dolazim k vama kao hodočasnik Evanđelja slijedeći stope prvih svjedoka vjere. [...] Dolazim učvrstiti svoju braću u vjeri zahvalan Gospodinu za dvotisućljetnu nazočnost Crkve u ovim krajevima i za bogatu povijest hrvatskih katolika. Dolazim da tu svoju braću ohrabrim u nadi i da ojačam njihovu ljubav. "3 Papa postavlja hodočasnički identitet i poslanje čovjeka trećeg tisućljeća, a samim tim i budućnost Crkve i hrvatskog naroda, na temelj triju bogoslovnih kreposti. Kroz njih čovjek ostvaruje svoje puno ozbiljenje slike Božje u Kristu. U skladu s tim drugi dio njegova naslova odnosi se na "Evanđelje" - temeljnu istinu kršćanske vjere da je Isus Krist Otkupitelj čovjeka. A čovjek je jedini put kojim Crkva ostvaruje svoje poslanje. ${ }^{4}$ Shodno tome Papa uvijek iznova osvjetljava identitet otkupljenog čovjeka u Isusu Kristu i tako definira njegov položaj i poslanje u suvremenom svijetu, ne zaboravljajući viziju budućnosti. Tako je i ovaj drugi pastirski pohod usmjeren upravo na čovjeka i njegovu povijesno-spasenjsku kristološku zbilju na pragu trećeg tisućljeća. Poslijeratnu stvarnost čovjeka, Crkve i društva valjalo je oživjeti novim proljećem vjere i

2 Usp. Ivan Koprek, Antropologija u misli Ivana Pavla II., u: Ines Sabotič - Željko Tanjić - Gordan Črpić (ur.), Ivan Pavao II. Poslanje i djelovanje, Zbornik radova, Glas Koncila, Zagreb, 2007., 77-83, ovdje 80.

3 Ivan Pavao II., Govor u zračnoj luci Pleso, Zagreb, 2. listopada 1998., 5-8, ovdje 6.

4 Usp. Ivan Pavao II., Redemptor hominis. Otkupitelj čovjeka, Kršćanska sadašnjost, Zagreb, 1980., br. 8. (dalje RH). 
izgradnjom kulture života $\mathrm{u}$ istinski demokratiziranom društvu, koje će voditi računa o očuvanju temeljnih ljudskih prava, zdravoj obitelji, njezinoj zadaći rađanja te odgoja mladeži i budućih naraštaja. U središtu tog procesa stoji iskonsko dostojanstvo čovjeka kao slike Božje. Nasuprot tome Papa upozorava: „Svako uređenje vlastitog života, koje nije u skladu s Božjim naukom o čovjeku, određeno je na neuspjeh, i to prije ili kasnije. Čovjek se naime jedino s Bogom i u Bogu može potpuno ostvariti i postignuti puninu prema kojoj teži iz dubina svojega srca."

Za Papu dvojbe nema: ostvarenje kvalitetne sadašnjosti i sigurne budućnosti moguće je samo ako hrvatski čovjek trajno bude tražitelj Istine objavljene u Kristu i ujedno svjedok otkrivenoga, a to znači hodočasnik Evanđelja.

\section{Čovjek bogotražitelj - hodočasnik Evanđelja}

U svjetlu Papina naslova "Hodočasnik Evanđelja”, valja razmatrati i odgovor na pitanje: tko je čovjek današnjice? Odgovor na to pitanje definira odnos pojedinca, Crkve i društva prema čovjeku trećeg tisućljeća. U svjetlu Radosne vijesti za Ivana Pavla II. je jasno da je čovjek potekao iz zamisli Božje ljubavi, te nadilazi zemaljske dimenzije, budući da je pozvan na dioništvo u samom Božjem životu. Odatle njegovo dostojanstvo već u ovozemaljskoj vremenitosti. Naslov "Hodočasnik Evanđelja" Papa ne prisvaja samo sebi, već ga smatra ključem za razumijevanje identiteta čovjeka. Nasuprot degradaciji čovjeka što ga je proklamirao materijalistički ateizam, Papa u skladu s Katekizmom Katoličke Crkve pred hrvatskim biskupima naglašava iskonski naum Božji s čovjekom: „Bog, neizmjerno savršen i blažen u sebi samom, u naumu čiste dobrote, slobodno je stvorio čovjeka da ga učini dionikom svog blaženog života. Zato je Bog uvijek i posvuda bliz čovjeku“ (KKC, 1). ${ }^{6}$ Tek u svjetlu Božje blizine otvara se čovjeku spoznaja dostojanstva samoga sebe kao bogotražitelja, iz koje slijedi poslanje: „Suvremenom je čovjeku, naime, potrebno upoznati i usvojiti vlastito dostojanstvo koje mu je sasvim besplatno udijelio Bog, koji ga je stvorio na svoju sliku i priliku (usp. Post 1, 26-27) i otkupio Kristovom krvlju (usp. Otk 5, 9).“7

5 Ivan Pavao II., Poruka vjeroučiteljima, nastavnicima i predstavnicima crkvenih pokreta, u Solinu, 4. listopada 1998., 43-48, ovdje 47.

6 Ivan Pavao II., Govor Svetog Oca hrvatskim biskupima, Nadbiskupski dvor u Splitu, 4. listopada 1998., 36-42, ovdje 42.

7 Govor Svetog Oca hrvatskim biskupima, 40. 
Otkriće vlastite bogolikosti u Kristu ljudski je odgovor na Božju samoobjavu i istodobno dar koji mu trajno upućuje Providnost poziv na vjeru. Vjera je istodobno svjedočenje otkrivene istine. Takvo poimanje Papa je naznačio već u svojoj programatskoj enciklici u kojoj naglašava da upravo iz vjere proizlazi duboko divljenje pred vrijednošću i dostojanstvom čovjeka, a to zapravo jest Evanđelje ili Radosna vijest, tj. kršćanstvo. ${ }^{8}$ Drugim riječima približavanje čovjeka Kristu, pritjelovljenje stvarnosti Utjelovljenja i Otkupljenja predstavlja traženje Istine i hodočašće prema Bogu. To je put vlastitog očovječenja, tj. spoznaja dostojanstva vlastitog identiteta, koje se nadalje osvjedočuje u ostvarenju zajedništvu s drugima, tj. izgradnji društva. Tu istinu Papa želi naglasiti kao ključ razumijevanja čovjeka i njegova osobnog poslanja u Hrvatskoj danas. Stoga nalaže hrvatskim biskupima: „Promaknuće dostojanstva osobe i obitelji te promaknuće prava na život, koje je danas posebno ugroženo, zajedno s obranom najslabijih društvenih slojeva, moraju imati posebno mjesto u sveukupnoj vašoj apostolskoj skrbi kako bi 'dali dušu' suvremenoj Hrvatskoj." ${ }^{9}$ Iz navedenog slijedi da tako osvijetljenom čovjekovom hodočasničkom identitetu u Kristu pripada imperativ obrane istoga, poradi vlastitog, ali i općeg dobra. Dostojanstvo čovjeka treba biti konstanta od koje sva suvremena nastojanja polaze i u njoj imaju svoj smisao. Budući da se isto nebrojeno puta potvrdilo kroz povijest, Papa ističe: „Životno je važno da hrvatski narod ostane vjeran svojim kršćanskim korijenima te da istodobno bude otvoren zahtjevima sadašnjeg trenutka koji, iako nosi ne male teškoće, ipak omogućuje nazrijeti utješne razloge nade.“10

$\mathrm{Na}$ taj način Ivan Pavao II. definira zadaće koje trajno stoje pred hrvatskim čovjekom, kako onda tako i danas, dva desetljeća kasnije, te očekuje: „Želja mi je da iz davnih kršćanskih korijena ove zemlje provre jaka bujica životne limfe koja će sad već u zoru novoga tisućljeća osigurati procvat istinskog humanizma za buduće naraštaje." "11 Kristovo otkupljenje je objava istinskog humanizma, tj. čovjeka bogotražitelja i svjedoka - hodočasnika. Na temelju toga Ivan Koprek zaključuje: „Ivan Pavao II. nuka postmodernog čovjeka koji živi nad ponorom beznadnosti da napusti 'ropski život', koji mu je nametnula današnja kultura zatvorivši ga u njegov razum i proizvode, te se prepusti nadi koju mu otvara Isus Krist.“12

\footnotetext{
$8 \quad$ Usp. RH, br. 10.

9 Govor Svetog Oca hrvatskim biskupima, 41.

10 Govor u zračnoj luci Pleso, 7.

11 Isto, 8.

12 Koprek, Antropologija u misli..., 80.
} 
Samo hodočašće usmjereno prema Kristu koji je izvor nade može biti istodobno izvor zajedništva prema bratu čovjeku, s kojim dijeli baštinu iste nade. Stoga je trajna potreba: „Danas je jednako kao i jučer našoj braći i sestrama potrebno upoznati Krista, poslanika Oca, koji je u ljudsko srce stavio klicu novoga i besmrtnoga života, života djece Božje. " ${ }^{13}$ Nasuprot tome, dovede li se u pitanje Istina za kojom čovjek traga i upoznavanje Krista, upitan je i život, vrijednosti i identitet, te poslanje čovjeka hodočasnika. Neosporna značajka suvremenog vremena, dvadeset godina nakon ovog Papinog pohoda, jest upravo marginalizacija Istine na temelju koje čovjek ostvaruje vlastiti identitet i dostojanstvo, kao i temeljno poslanje izgradnje zajedništva. Samim tim nameću se poluistine, koje namjesto čovjeka naglašavaju profit kao temeljnu vrijednost, a umjesto zajedništva utemeljenog na Kristu virtualno zajedništvo, koje vodi u osamljenost, beznađe, ropstvo i samu smrt. Nasuprot tome, ustroj koji je Bog utisnuo u čovjeka hodočasnika i sve stvoreno pruža iskonsko i neprolazno dostojanstvo čovjeka te nadu i sigurnost njegova poslanja.

\section{SLuŽEnJe I POSLANJE CRKVE}

U skladu s definiranjem čovjeka kao tražitelja Istine i hodočasnika Evanđelja te kršćanstva kao divljenja nad njegovim dostojanstvom Ivan Pavao II. u propovijedi na Žnjanu u Splitu vidi Crkvu kao braniteljicu života i navjestiteljicu iste Radosne vijesti svakom čovjeku i ističe njezinu božansku i ljudsku dimenziju: „U tom se pak djelu propovijedanja Radosne vijesti, koje je istodobno i Božje i ljudsko, valja oslanjati na Gospodinovu snagu." ${ }^{14}$ Riječ je o Istini objavljenoj u Kristu - Otkupitelju čovjeka. Takva kristocentrična ekleziologija, ključna je za Papino učenje. ${ }^{15}$ Osnovni zadatak Crkve je tako trajno upravljati čovjekov pogled prema Kristovu Otajstvu. ${ }^{16}$ U Papinu govoru o Crkvi i čovjeku koji je njezin put u konačnici je riječ o soteriologiji. ${ }^{17}$ Shodno tome on ponavlja u propovijedi u Splitu da je Crkva ovdje "na zemlji klica i početak" Kraljevstva nebeskoga

13 Govor Svetog Oca hrvatskim biskupima, 42.

14 Ivan Pavao II., Govor na Žnjanu u Splitu, 4. listopada 1998., 27-33, ovdje 29.

15 Usp. Bernhard Häring, Kommentar, u: Johannes Paul II, Die Würde des Menschen in Christus. Die Antrittsenzyklika "Redemptor hominis". Mit einem Kommentar von Bernhard Häring CSsR, Herder, Freiburg - Basel - Beč, 1979., 123.

16 Usp. RH, br. 10.

17 Usp. Nela Gašpar, Kristologija Ivana Pavla II., u: I. Sabotič - Ž. Tanjić - G. Črpić (ur.), Ivan Pavao II. Poslanje i djelovanje, 61-75, ovdje 62. 
$(L G, 5) .{ }^{18}$ Bit Crkve je oživotvorenje Božje ljubavi prema čovjeku, ali i svakog čovjeka prema Bogu te ljudi međusobno. U skladu s navedenim, a na temelju ovih Papinih poruka Nikola Dogan zaključuje: „Načelno, zadaća Crkve je služenje evanđeoskoj Poruci, međutim gledamo li konkretnije, papa naglasak stavlja na služenje dobru osobe, pravom dobru osobe, u konačnici služba Crkve je 'služenje čovjeku'."19 Takvo služenje u ljubavi prepoznaje znakove vremena, ubire plodove baštine, ali je usmjereno konačnom zajedništvu. Stoga Papa naglašava potrebu iste zauzetosti i u novim prilikama: „Naš Otkupitelj jasno želi zajedništvo svih vjernika i ono je bitni čimbenik svakog apostolskog djelovanja i temelj svake evangelizacije. [...] Potrebno je da Crkva koja je u Hrvatskoj učvrsti zajedništvo svih svojih različitih snaga kako bi postignula ciljeve koji su pred njom u današnjem ozračju slobode i demokracije. ${ }^{20}$ Pri tom zalaganju za čovjeka važno je nastojanje klera na čelu s biskupom oko dušobrižništva svećeničkih i redovničkih zvanja i poticanje sustavnog i pouzdanog pastorala obitelji, te dušobrižništvo novih naraštaja. Takva nastojanja nadalje urodit će plodom u zalaganju laika oko izgradnje obitelji kao kućne crkve, obrane kulture života te rađanja i odgajanja budućih naraštaja. ${ }^{21} \mathrm{~K}$ tome, u obraćanju predstavnicima crkvenih udruga i pokreta poziva: „Vjernici svjetovnjaci imaju vlastito mjesto u Crkvi. Snagom su primljenog krštenja pozvani na sudjelovanje u jednom i općem poslanju Crkve (usp. $L G, 33,38$; $A A, 3$ ), svatko prema primljenim darovima. Potrebno je stoga poticati zdravi pluralizam raznih oblika udruživanja, odbacujući isključivosti, kako bi se stvorio prostor za karizme, koje Duh Sveti ne prestaje dijeliti u Crkvi radi izgradnje Kraljevstva Božjega i dobra čovječanstva." 22

Jasno je da zajedništvo traži iskrenu međusobnu suradnju različitih sastavnica Crkve, otvorenost i posluh pastirima, u zajedništvu s rimskim biskupom te ustrajnost klera i vjernika $\mathrm{u}$ apostolskom nauku, bratskom zajedništvu, u lomljenju kruha i u molitvi (usp. Dj 2, 42). ${ }^{23} \mathrm{Na}$ temelju izrečenoga očite su četiri bitne značajke Crkve: jedna - poslana navijestiti Radosnu vijest svakom čovjeku bez izuzetka, sveta - po božanskoj dimenziji otkupljenja u Kristu, Otkupitelju čovjeka, katolička - po zajedništvu i doprinosu svih sta-

18 Usp. Govor na Žnjanu u Splitu, 32.

19 Nikola Dogan, Pastoralne poruke i poticaji Ivana Pavla II. prigodom drugoga pohoda Hrvatskoj 1998., Bogoslovska smotra, 69 (1999.) 2-3, 233-254, ovdje 236.

20 Govor Svetog Oca hrvatskim biskupima, 37.

21 Usp. isto, 41.

22 Poruka vjeroučiteljima, nastavnicima i predstavnicima crkvenih pokreta, 44-45.

23 Usp. Govor Svetog Oca hrvatskim biskupima, 37. 
leža te apostolska - poslušna apostolskom nauku u zajedništvu s rimskim biskupom usprkos protivštinama. Ukoliko se bilo koja od tih dimenzija dovede $u$ pitanje, doveden je u pitanje sam identitet Kristove Crkve, a time i njezin put - čovjek. Stoga suvremene prilike, dvadeset godina nakon ovog pohoda, više nego ikad zahtijevaju novu evangelizaciju, temeljenu na potrebama i dostojanstvu suvremenog čovjeka, a u skladu s iskonskim atributima Crkve.

\subsection{Nova evangelizacija - svjedočanstvo Istine u novim prilikama}

Govoreći o daru poziva na vjeru koji Providnost upravlja čovjeku i svjedočanstvu tog poziva Papa se divi nepokolebljivoj i mučeničkoj baštini koja obvezuje. Čovjek, kultura i običaji društva trajno žive ubirući plodove tog poziva. Stoga je permanentno naviještanje čovjekove vjernosti savezu s Kristom i Crkvom - ovdje i danas, zadaća koja nema alternativu, uvijek oslonjena na Gospodinovu snagu, ma koliko vremena bila protivna. ${ }^{24}$ Pri tom riječ je uvijek o istom daru otkupljenja čovjeka u Kristu, ali novim svjedocima i okolnostima: „Govorimo o potrebi nove evangelizacije: nove s obzirom na način, ali uvijek iste što se tiče istina koje valja navješćivati. Nova je evangelizacija golem zadatak: sveopći s obzirom na sadržaj i odredište, praćen potrebom prilagodbe različitim zahtjevima pojedinih krajeva،“"25

Papa je svjestan promjena koje su zavladale na pragu trećega tisućljeća i iskrivljenih antropologija suvremenog vremena, koje imaju nesagledive posljedice za čovjeka, Crkvu i društvo. Shodno tome Papa inzistira na "novom proljeću vjere" u hrvatskim krajevima, obnovljenom propovijedanju istog Kristova Evanđelja u svim društvenim sredinama, što ima dovesti ubiranju plodova u ostvarenju dostojanstva i prava svakog čovjeka, upoznavanju mira i izgradnji suživota velike ljudske obitelji. ${ }^{26}$ Razlog tomu Đuro Hranić sažima ovako: „Ivan Pavao II. namjerava staviti Krista u središte čitave povijesti spasenja i u središte ljudskog života: u njemu je Bog odvijeka čovjeka izabrao i predodredio ga da postane posinak Božji. Ovo posinstvo, prema Ivanu Pavlu II., predstavlja dovršenje eshatološkog čovjekovog poziva." 27

\footnotetext{
24 Usp. Govor na Žnjanu u Splitu, 29, 31.

25 Isto, 29.

26 Usp. Govor na Žnjanu u Splitu, 31.

27 Đuro Hranić, Kristološki naglasci u učenju Ivana Pavla II., u: I. Sabotič - Ž. Tanjić - G. Črpić (ur.), Ivan Pavao II. Poslanje i djelovanje, 13-59, ovdje 32.
} 
Vrijeme Crkve navjestiteljice treba karakterizirati aktualan proces služenja Evanđelju, tj. konkretnom čovjeku koji je usmjeren prema vječnosti, ali je još uvijek u kontekstu svoga vremena. Zato Papa potiče: „Crkva danas ima mogućnost upotrebe raznovrsnih sredstava evangelizacije i pristupa svim dijelovima društva. Ovo je prigodna zgoda koju Providnost pruža današnjem naraštaju za propovijedanje Evanđelja i svjedočenje Isusa Krista, jedinoga Spasitelja svijeta, pridonoseći tako izgradnji društva po mjeri čovjeka."28

Istu je misao osim u propovijedi u Splitu Papa istaknuo i u susretu s hrvatskim biskupima, naglašavajući potrebu da se u konkretnom vremenu raspiri žar vjere u Krista, koja dalje vodi k očovječenju čovjeka i ostvarenju njegova identiteta vlastite kristolikosti, te ga u vlastitoj sredini postavlja u svjedočansku službu i zalaganje za čovjeka. Takva je sredina onda zasigurno potpuno suprotna onoj koju je propagirao ateistički materijalizam, ali istodobno i alternativa prijetećim izazovima konzumizma i hedonizma. ${ }^{29}$ Samo evangelizacijom očovječena sredina predstavlja skupa s čovjekom sakrament Božje ljubavi i njegovu vjernu sliku. Takva evangelizacija srž je poslanja Crkve, osvjedočena molitvenim i sakramentalnim zajedništvom. ${ }^{30}$ Tome valja pridodati i ekumenska i međureligijska nastojanja. To nije nikakav poseban zahtjev, već samo znak zajedničkog evanđeoskog svjedočenja i veličine ponizne vjere koja izvodi silna djela. ${ }^{31}$ Budući da je takvo svjedočanstvo uvijek pratio i otpor, mučeništvo je svojevrsni dokaz pravovjernosti Crkve. U tom smislu Dogan zaključuje: „Gledajući Crkvu u njezinim povijesnim koracima, u njezinu Božanskom poslanju, osobito pak u novijim vremenima, papa zaključuje kako je mučeništvo, povezano s Kristom i u Kristu, svakodnevni život Crkve. Crkva se mora trajno i stalno u ime Kristovo boriti protiv svih zala, protiv svih režima i društava, koja ne ostvaruju Kristovu zapovijed ljubavi." ${ }^{2}$

Iz svega izrečenoga zaključujemo da istina o čovjeku, kao biću koje je pozvano na vjeru, koji kroz svoje vjerničko hodočašće otkriva bit vlastitog identiteta i zajedništva, treba i danas, dvadeset godina nakon pastirskog pohoda, u novim prilikama i nasuprot antropologijama koje nastoje orobiti čovjeka u njegovoj duhovnoj sferi, uroditi svjedočanskim plodovima u Crkvi, ali i u izgradnji društva po mjeri čovjeka. To su ponajprije plodovi molitvenoga i sakramentalnog

\footnotetext{
28 Govor na Žnjanu u Splitu, 31.

29 Usp. Govor Svetog Oca hrvatskim biskupima, 38.

30 Usp. Poruka vjeroučiteljima, nastavnicima i predstavnicima crkvenih pokreta, 45.

31 Usp. Govor na Žnjanu u Splitu, 32-33.

32 Dogan, Pastoralne poruke i poticaji..., 238.
} 
zajedništva s Istinom, objavljenom u Isusu Kristu, koje se istodobno treba nastaviti kako u jedinstvu mjesne Crkve, tako i u nepokolebljivom zajedništvu s rimskim biskupom te konačno $u$ hodočašću ljudi međusobno. Iz istog razloga Papa u svojim susretima u Splitu i Solinu, zagovarajući svjedočansku Crkvu, posvećuje posebnu pozornost konkretnom evanđeoskom svjedočanstvu obitelji i mladih.

\subsection{Obitelj - kućna Crkva}

Vodeći računa o čovjekovu pozivu na zajedništvo, obitelj je spona Crkve i društva po mjeri čovjeka. Stoga bismo u okviru Papine poruke o identitetu i poslanju obitelji mogli razmišljati kako u kontekstu poslanja Crkve tako i poslanja društva. Ipak, u obraćanju hrvatskim biskupima, a u skladu s apostolskom pobudnicom Familiaris consortio, Ivan Pavao II. definira identitet obitelji kao "kućnu Crkvu kroz koju ide budućnost svijeta i Crkve $(F C, 75)$ ". ${ }^{33}$ Ta istina vezuje se na ideju identiteta čovjeka kao hodočasnika Evanđelja i njegova poslanja u službi nove evangelizacije i demokratizacije društva na temelju moralnih vrijednosti. Papa jezgrovito poistovjećuje obitelj s mjestom života, zajedništva, vjere i ljubavi. Ona je sredina u kojoj život svakog čovjeka treba biti ne samo prihvaćen nego i zaštićen. Rađanje je dar koji proizlazi iz iskonskog darivanja, egzistencije radi proegzistencije. ${ }^{34}$ Nadalje, Božji nacrt stvaranja ogleda se $u$ obitelji ne samo u činu prokreacije i zajedništva nego i u poslanju odgoja koji pridonosi da svaka osoba raste na sliku Božju objavljenu u Isusu Kristu i tako bude hodočasnik Evanđelja. Iz istog razloga Papa pojašnjava: „Hrvatskoj su u ovo doba velikih promjena i preobrazbi potrebni muževi i žene žive vjere, koji znaju svjedočiti Božju ljubav prema čovjeku i koji su spremni staviti svoje snage u službu Evanđelja. Vašoj su naciji potrebni apostoli koji će poći među svijet noseći radosnu vijest. [...] Na njima je zadatak da te sredine prožmu Kristovim Duhom na korist svega društva."35

Zaključujemo da je obitelj neprolazno rasadište života te istodobno sjemenište vjere u kojoj se rađaju i rastu takvi svjedoci. Budući da je svojim poslanjem usmjerena životu, njegovom očuvanju i rastu, što vodi općem dobru i svekolikom zajedništvu i napretku u skladu s Božjim naumom, ona je kućna Crkva.

33 Govor Svetog Oca hrvatskim biskupima, 40.

34 Usp. isto, 41-42.

35 Govor Svetog Oca hrvatskim biskupima, 39. 


\subsubsection{Obrana kulture života}

Kad je riječ o naravi obitelji, za Papu je ključno da ona počiva na kršćanskom poimanju ženidbe. Time se prije svega misli na iskonski ustroj koji je Bog utisnuo u čovjeka, njegovu sakramentalnu svetost, zajedničko dobro muškarca i žene te rađanje i odgajanje potomstva. Nasuprot tome suvremeno društvo trpi u raskoraku između izvornog poslanja obitelji usmjerene na život i izgradnju zajedništva, s jedne strane, i egoističnih mogućnosti, s druge strane. Stoga je, smatra Papa, osobito svjedočansko poslanje Crkve danas usmjereno prema obrani i očuvanju "kulture života", a pred naletom "kulture smrti". ${ }^{36}$ Shodno tome on svrstava zla pobačaja, eutanazije i rata u najopakije zločine protiv čovjeka, koji su u suprotnosti s iskonskim Božjim darom i pozivom upućenim čovjeku da živi blaženim životom dok konačno ne uzme udjela na njegovoj punini u vječnosti. Skrećući pozornost na suvremeno evangelizacijsko djelovanje Crkve i na ustroj koji je Bog utisnuo u čovjeka, ističe: „Obrana je života sastavni dio poslanja Crkve. [...] Dušobrižničko djelovanje na tome području mora svraćati pozornost na ustroj, koji je Bog utisnuo u čovjeka i svekoliko stvorenje."37 Upravo to je uloga povjerena obitelji u Crkvi da bude "svetište života", te ga čuva i naviješta kao Evanđelje Božje ljubavi za čovjeka i Evanđelje dostojanstva svake osobe. ${ }^{38}$ Povezujući tako identitet čovjeka s dostojanstvom i ulogom obitelji, Papa je želio istaknuti trajnu vrijednost obiteljskog zajedništva, koje je izvor, pratitelj i vodič na putu traženja Istine i hodočasničkog svjedočenja Istine. Drugim riječima, bez obitelji i očuvanja života u njoj nema ni hodočasnika Evanđelja. Kao takva, obitelj nema alternativu, niti smije pokleknuti pred izazovima i ponudama potrošačkoga i neoliberalnog društva. Shodno tome, obitelj ima stožerno mjesto u oblikovanju vjerskog i nacionalnog identiteta samog čovjeka, ali i društva u cjelini. Kroz obitelj Crkva i društvo neprestano se prožimaju i nadopunjavaju, sa zadaćom očuvanja kulture života u skladu s Božjim naumom o čovjeku.

\subsubsection{Djeca i mladež - zalog budućnosti}

Tijekom pastirskog pohoda splitskoj Crkvi, Papa se osobito želio susresti s mladima, i to u Solinu, u okrilju Gospe od Otoka. To

\footnotetext{
36 Isto, 42.

37 Isto.

38 Usp. Ivan Pavao II., Evangelium vitae. Evanđelje života, Kršćanska sadašnjost, Zagreb, 2003., br. 2 i 6 (dalje EV).
} 
mjesto prepoznato je kao "vrelo hrvatskog kršćanskog identiteta". ${ }^{39}$ Vjernost tom i takvom kršćanskom identitetu osposobljava čovjeka od najranije dobi za izbor pravih istina i svjedočansko preuzimanje budućnosti pojedinca, Crkve i domovine u vlastite ruke. Valentina Mandarić zaključuje kako je Papa "u mladima vidio znak bolje budućnosti za svijet, za društvo, za Crkvu". ${ }^{40}$ Kao primarno mjesto osposobljavanja mladeži za ostvarenje tih ideala Papa prije svega ističe obitelj, ali istodobno naglašava važnost školskih i odgojnih ustanova, te svjedočansku ulogu nastavnika i vjeroučitelja, jer: „Mladeži je potrebno svjedočanstvo ljubavi koja se zna žrtvovati, i strpljivosti, koja zna čekati s pouzdanjem. " ${ }^{11}$

Istinsko svjedočanstvo predstavlja zalog budućnosti, koja je $u$ rukama mladih, jer "ulaganje u odgoj novih naraštaja znači ulaganje u budućnost Crkve i nacije". ${ }^{42}$ Pritom, za Papu je izrazito bitan triptih potpunog čovjeka i rast na svim poljima osobnosti: „Svaki odgojni nacrt, da bi mogao postignuti svoju vlastitu svrhu, mora biti bogat duhovnim, ljudskim i kulturnim vrijednostima." 43

Imperativ izgrađivanja čovjeka na svim područjima osobnosti, u skladu s evanđeoskim vrijednostima, preduvjet je otkrića i divljenja nad vlastitim dostojanstvom i hodočašća evanđelja. Stoga Papa potiče biskupe: „Ne zaboravite ni dušobrižništvo novih naraštaja. Njima pripada budućnost. Dobro će odgojena mladež biti u stanju osnovati dobre obitelji, a te će obitelji biti sposobne dobro odgajati svoju djecu. " ${ }^{44} \mathrm{U}$ tim riječima dade se iščitati ista narav života kao dara Providnosti i poziv darovano dalje darivati. Papa prepoznaje nepobitnu važnost evanđeoskog pristupa mladom čovjeku, budući da se time gradi zajedništvo i u Crkvi i u društva. Nasuprot tome marginalizacijom odgoja utemeljenog na evanđeoskim vrijednostima krivo se definiraju svi međusobni odnosi čovjeka, on sam biva zarobljen u vlastitom životu, ne pruža svjedočanstvo ljubavi koja je spremna žrtvovati se za drugoga, niti posjeduje strpljivost koja čeka u nadi i $\mathrm{s}$ pouzdanjem. Upravo u tom devijantnom pristupu dade se iščitati uzroke krize i pomanjkanja nade mladih današnjice.

39 Usp. Poruka vjeroučiteljima, nastavnicima i predstavnicima crkvenih pokreta, 44, 47.

40 Valentina Mandarić, Mladi - nada Crkve i svijeta, u: I. Sabotič - Ž. Tanjić - G. Črpić (ur.), Ivan Pavao II. Poslanje i djelovanje, 183-196, ovdje 191.

41 Poruka vjeroučiteljima, nastavnicima i predstavnicima crkvenih pokreta, 46.

42 Isto, 45.

43 Isto.

44 Govor Svetog Oca hrvatskim biskupima, 41. 


\section{DOPRINOS KRŠĆANA IZGRADNJI DRUŠTVA}

Pastirski pohod ujedno je pohod i hrvatskom društvu. Svjestan prijelomnog trenutka u kojem se našao hrvatski narod, Papa zorno pristupa patničkoj baštini, obilježenoj totalitarnim ideologijama i izazovima zla. Istodobno, sva stoljeća pratilo je i neustrašivo naviještanje Evanđelja. Ne omalovažavajući trpljenja kroz koja je prošao hrvatski narod, Papa želi istaknuti tri bitne vrednote koje su očuvale hrvatski identitet kroz povijest, te predstavljaju trajan zalog budućnosti. Taj egzistencijalni triptih hrvatskog društva isticao je Ivan Pavao II. i ranije u svom obraćanju Hrvatima. ${ }^{45}$ Riječ je o vjernosti Hrvata krsnom zavjetu, zatim rimskom biskupu i konačno Blaženoj Djevici Mariji - Kraljici Hrvata. Za Papu to je jedini put koji može dovesti do izgradnje zemlje i društva na moralnim vrijednostima i procvata istinskog humanizma za budućnost. ${ }^{46}$ Premda se napredak odnosi na hrvatsko društvo u cjelini, očito je da Papa u prvom redu govori o zadaći i odgovornosti kršćana za svoju domovinu. Riječ je o stavu Crkve o osnovnim postavkama društva u suvremenom svijetu. ${ }^{47} \mathrm{U}$ tom kontekstu Papa u Splitu pojašnjava što je poslanje hrvatskog društva za treće tisućljeće i tvrdi: „Kršćani su u hrvatskim krajevima danas pozvani dati novo lice svojoj domovini, posebno se zalažući da se u društvu ponovno učvrste etičke i moralne vrijednosti, što su ih potkopali prijašnji totalitarizmi i nedavno ratno nasilje. Ta zadaća zahtijeva veliku snagu i odlučnu volju. A zadaća je žurna, jer bez tih vrijednosti nema ni prave slobode ni istinske demokracije." 48

Nakon što čovjek kao bogotražitelj - hodočasnik otkrije vlastitu kristolikost, dalje je poslan izgrađivati društvo po mjeri čovjeka, tj. u skladu s Božjim naumom, dati novo lice domovini u slobodi i istinskoj demokraciji, posebno se zalažući za etičke i moralne vrijednosti, počevši od temeljne vrijednosti poštivanja ljudskog života, preko poštivanja prava i dostojanstva osobe sve do poštivanja prava i dostojanstva svakog naroda. ${ }^{49}$ Ostvarenje takvih velikih djela permanentan je izazov društva u novim prilikama $u$ kojima se na početku trećega tisućljeća nalazi hrvatski narod. Upravo zato,

45 Usp. Božidar Nagy (prir.), Papa Ivan Pavao II. govori Hrvatima. Svi pozdravi, govori i poruke pape Ivana Pavla II. koje je uputio Hrvatima za vrijeme svojega pontifikata od 1978. do 2005., Filozofsko teološki institut DI, Zagreb, 2011, 52.

46 Usp. Govor u zračnoj luci Pleso, 8.

47 Usp. Dogan, Pastoralne poruke i poticaji..., 244.

48 Govor na Žnjanu u Splitu, 32.

49 Usp. isto. 
razlažući ovu žurnu zadaću iz Papinih riječi izdvajamo dva osnovna poslanja društva, aktualna i danas, a to su liječenje povijesnih rana i demokratizacija.

\subsection{Liječenje rana}

Povijest svjedočanstva hrvatskih katolika pokazuje stalno postojanje razloga nade usprkos izloženosti neljudskim pogiblima. Vezano uz posljednje iskustvo krvavog Domovinskog rata Papa ističe: „Sve su snage pučanstva sada usmjerene na postupno liječenje dubokih rana sukoba, na istinsko pomirenje među svim etničkim, religioznim i političkim komponentama stanovništva i prema uvijek sve većoj demokratizaciji društva."50 Očito je da liječenje rana prošlosti predstavlja neodgodivi preduvjet izgradnje zajedništva i napretka društva u cjelini. Razmatrajući isti poziv koji je Hrvatima upućen i za vrijeme prvoga pastirskog pohoda Hrvatskoj 1994. godine, Darko Grden zaključuje da je "istinski slobodan samo onaj pojedinac i ona zajednica koji ne dopuštaju da prošlost zatvori vrata budućnosti". ${ }^{51}$ Da bi nasuprot svim zlima povijesti zavladao mir ljudske obitelji, neophodno je razumijevanje, uzajamno poštivanje, praštanje i pomirba. Svoj doprinos tome svjedočeći nadu trebaju pravodobno i iskreno pružiti svi, od međunarodne zajednice do svakog pojedinca. ${ }^{52}$ Dakako, svjestan teškoće sadašnjeg trenutka Papa ističe: „Ratne posljedice i način razmišljanja stvoren u doba komunističke vladavine stvaraju brojne zapreke. Prijeko je potrebno ne klonuti duhom. Solidarnom se suradnjom svih mogu i u razmjerno kratkom roku naći prikladna rješenja čak i za najsloženija pitanja."53

Stožerna točka na kojoj valja temeljiti liječenje povijesnih rana i podjela te izgrađivati zajedničarsku budućnost čovjeka, društva i Domovine svakako je ustrajan hodočasnički identitet čovjeka prema Evanđelju te naviještanje nove nade, praštanja, zajedništva i mira. U današnjem suvremenom društvu, dva desetljeća nakon ovog pastirskog pohoda, valja prepoznati važnost istog puta konačnog ozdravljenja rana razdjelnica u svakom čovjeku, kao jedini način otvaranja vrata zajedništva i napretka društva u slobodi i demokraciji.

50 Govor u zračnoj luci Pleso, 7.

51 Darko Grden, "Budite narod nade!”, u: I. Sabotič - Ž. Tanjić - G. Črpić (ur .), Ivan Pavao II. Poslanje i djelovanje, 347-351, ovdje 349.

52 Usp. Ivan Pavao II., Anđeosko pozdravljenje, Žnjan, 4. listopada 1998., 33-35, ovdje 34.

53 Govor u zračnoj luci Pleso, 7. 


\subsection{Demokratizacija - izgradnja društva po mjeri čovjeka}

Nakon komunističkog totalitarizma i krvavog rata Papa vidi ponajprije kršćane kao kreatore demokratizacije društva, budući da prava demokratizacija mora imati svoj moralni oslonac. Dogan pojašnjava: „Bit moralnih temelja za demokratizaciju papa nalazi u Bogu. Zakon Božji mora biti nadahnuće i osnova demokratskog društva u Hrvatskoj. "54 Riječ je o odgovornosti davanja novog lica domovini, zalažući se za promicanje općeg dobra i ponovno učvršćivanje etičkih i moralnih vrijednosti, koje su temelj slobode i istinske demokracije. Čovjek, njegov identitet i dostojanstvo mjera su po kojoj se izgrađuje skupocjeno zajedništvo: „Cijena je demokracije velika. Novac kojim se plaća ta cijena izrađuje se od plemenitih kovina čestitosti, razboritosti, poštivanja bližnjega, požrtvovnosti, strpljivosti." 55

U skladu s izrečenim, a budući da kršćanstvo gleda sugrađane kao braću i sestre, riječ je i o poštivanju prava i dostojanstva svakog naroda, bio u manjini ili većini. ${ }^{56} \mathrm{U}$ tom duhu Papa potiče hrvatske biskupe da prednjače cijelom narodu u nastojanju oko demokratizacije, "kako bi 'dali dušu' suvremenoj Hrvatskoj”. ${ }^{57}$ Samo zalaganjem svih moguće je nastaviti proces demokratizacije društva. Takav proces treba neizostavno biti u skladu s Božjim naukom o čovjeku, inače je unaprijed osuđen na neuspjeh. U pitanju je dakle opstojnost čovjeka, a ne samo društva.

4. Kraluica Hrvata i Bl. AlojziJe Stepinac - Slika Čovjeka, CRKVE I DRUŠTVA

Dezorijentiranost čovjeka na pragu trećeg tisućljeća uzrokovana je bezbožnim diktaturama povijesti, ali i strahom pred diktaturom relativizma i neoliberalizma sadašnjosti. Usprkos svim izazovima, Isus Krist je konstanta svakog vremena. Ivan Pavao II. naglašava da je čvrsta povezanost s njim, poput otajstva utjelovljenja pod Marijinim srcem, izvor čovjekova hodočasničkog identiteta, a beskompromisno svjedočanstvo, poput onoga bl. Stepinca, uzor je svakog poslanja te preduvjet mirne savjesti, koja je znak izvornog sklada,

54 Dogan, Pastoralne poruke i poticaji..., 251.

55 Ivan Pavao II., Govor u zračnoj luci u Splitu na završetku pastirskog pohoda, 4. listopada 1998., 49-52, ovdje 51-52.

56 Usp. Govor na Žnjanu u Splitu, 32.

57 Govor Svetog Oca hrvatskim biskupima, 41. 
nade i čovjekove slobode. Stoga su Blažena Djevica Marija i bl. Alojzije Stepinac trajan pokazatelj suvremenom čovjeku, Crkvi i društvu da je Bog temelj njihova identiteta i poslanja.

\subsection{MARIJA - ZNAK NOVOG ČOVJEKA I NJEGOVE NADE}

Pastirski pohod Ivana Pavla II. Hrvatskoj 1998. godine bilo je marijansko hodočašće, ponajprije u svetište Gospe Bistričke, a potom u Solin. Marija je za Papu primjer otkupljenog čovještva. Vlado Košić govori o njegovu "udivljenju pred ‘ženskim genijem'. A Marija je upravo takva žena koja najbolje utjelovljuje ženski genij, pod čime je on podrazumijevao ono specifično žensko što treba obogaćivati život suvremenog svijeta". ${ }^{58}$ Onu stvarnost koju čovjek ostvaruje kroz hodočašće Evanđelja, Marija je u sebi unaprijed osvjedočila po utjelovljenju Isusa Krista i donošenju njegove istine i bića drugima. Ona je novi čovjek, čovjek nade, hodočasnik Evanđelja. U njoj se prepoznaje čovjek otkupljen otajstvom Spasenja, koji u konkretnom društvu i Crkvi ostvaruje otajstvo Božjeg nauma. Stoga, govoreći o snažnoj povezanosti čovjeka, Crkve i naroda s Kristovom Majkom, osobito kad se nađu u trenucima teških iskušenja, Papa ponavlja važnost njezina patronata nad identitetom i svjedočanskim poslanjem te kaže: „Sve vas povjeravam Onoj, koja je bila tjelesna Majka Riječi utjelovljene radi našega spasenja. Gospa od Otoka iz ovog je svojeg prasvetišta u zemlji hrvatskoj bdjela nad vama, nad vašim obiteljima, nad vašom domovinom. Neka vam bude potpora u svjedočenju za Krista u novome tisućljeću, koje je već pred vratima."59

Marija je tako slika novog čovjeka - hodočasnika, pralik Crkve u novoj evangelizaciji i ogledalo suvremene društvene stvarnosti, koju čovjek danas treba postići trajnom demokratizacijom društva po mjeri čovjeka, na moralnim vrijednostima.

\subsection{Bl. Alojzije Stepinac - čovjek Crkve i društva za treće tisućljeće}

U kard. Stepincu Papa vidi častan primjer identiteta suvremenog svjedoka za evanđeoske istine te borca za dostojanstvo osobe i demokratizaciju društva. Svetost njegova svjedočanskog identiteta

58 Vlado Košić, Mariologija u misli Ivana Pavla II., u: I. Sabotič - Ž. Tanjić - G. Črpić (ur.), Ivan Pavao II. Poslanje i djelovanje, 169-182, ovdje 182.

59 Poruka vjeroučiteljima, nastavnicima i predstavnicima crkvenih pokreta, 48. 
za Ivana Pavla II. je neupitna: „U kardinalu Alojziju Stepincu blista u punini katolički odgovor: vjera u Boga, poštivanje čovjeka, ljubav prema svima potvrđena praštanjem, jedinstvo s Crkvom vođenom Petrovim nasljednikom."60

Stepinac je svijetli primjer pobjede Evanđelja nad totalitarnim sustavima, Božjega prava i savjesti nad nasiljem, praštanja nad mržnjom i osvetom. Njegovo je proglašenje blaženim svojevrsna rehabilitacija svih koji su kroz povijest hrvatskog naroda ljubili i činili pravednost, a stradali su zato što se nisu slagali sa službenim jednoumnim viđenjem vlastodršca. ${ }^{61}$ On i svi svjedoci vjere dokaz su neprolaznih vrednota i vječnog dostojanstvenog identiteta čovjeka $u$ Kristu. Papa ga tako vidi kao primjer evangelizacije i sliku hrvatskog društva na pragu trećeg tisućljeća. ${ }^{62}$ Njegovo je svjedočanstvo trajan poziv na nasljedovanje u izgrađivanju sadašnjosti i budućnosti na čvrstim temeljima kreposti vjere, nade i ljubavi prema Bogu i svakom čovjeku: „Njemu iskazana čast na određeni način se prelijeva i na sve vas. Pravo je da se time ponosite. Ali je također pravo i da se osjećate obveznima biti na visini jedne takve baštine, koja vam služi na čast, ali koja vas i obvezuje."63

Drugim riječima, čovjek trećega tisućljeća pozvan je poput bl. Stepinca vjerno svjedočiti evanđeoske vrijednosti, beskompromisno ostati odan rimskom biskupu i usprkos svim protivštinama u pobožnosti Mariji postajati novi čovjek. To je trajni put čovjeka, ali i Crkve i društva, do nade, smisla i uspjeha, tj. do punine prema kojoj stremi poradi vlastite bogolike naravi.

\section{ZAKLUUČAK}

Razmatrajući s vremenskim odmakom od dva desetljeća poruke koje je Ivan Pavao II. uputio tijekom drugoga pastirskog pohoda Hrvatskoj, s osobitim naglaskom na one izrečene u Splitu i Solinu, željeli smo nanovo osvijetliti trajne vrijednosti bitne za sadašnji trenutak, ali i budućnost hrvatskog čovjeka, Crkve i društva. Da bi se takve vrijednosti iskristalizirale i u svijesti zasjale u punom svjetlu, potreban je vremenski odmak, koji će pokazati i neželjene posljedice do kojih je došlo upravo zbog otklona od orijentacijskih istina. Glo-

\footnotetext{
60 Ivan Pavao II., Osvrt na apostolski posjet Hrvatskoj prilikom generalne audijencije u srijedu, Vatikan, 7. listopada 1998., 53-57, ovdje 54.

61 Usp. Grden, “Budite narod nade!”..., 349.

62 Usp. Osvrt na apostolski posjet Hrvatskoj..., 55.

63 Govor u zračnoj luci u Splitu..., 50.
} 
balna potrošačka kultura neoliberalnoga kapitalizma i konzumerizam koji su početkom trećeg tisućljeća zahvatili i hrvatsko društvo, inzistiraju na tržištu i potrošnji, marginalizirajući identitet i poslanje čovječnosti. Tako shvaćen društveni napredak stvara sve veće podjele u društvu, daleko je od demokratizacije i moralno je neodrživ, budući da su humane vrijednosti potpuno izokrenute: čovjek je postao rob sustava i tržišta, umjesto da sustav i društvo služe dobru čovjeka. Time je sputan istinski demokratski napredak društva na moralnim vrijednostima, prilagođen čovjeku i kulturi života. Održivi razvoj društva na početku trećeg tisućljeća zahtijeva odbacivanje čisto tržišnih interesa. Goruća rasprava u današnjem društvu o pitanjima rađanja, braka i obitelji pokazuje da ono što se predstavlja progresivnim, a nije utemeljeno na Bogu, vodi u beznađe, destrukciju i samu smrt. Tome u prilog govori i aktualni problem pada nataliteta te masovno iseljavanje iz domovine, pretežito mladih ljudi i čitavih obitelji. Izlaz iz postojeće situacije je ponajprije u naglašavanju pravog identiteta čovjeka, koji je tražitelj Istine i hodočasnik Evanđelja u izgradnji zajedništva. Promjene kroz koje prolazi Crkva i društvo traže, kako prije dvadeset godina tako i danas, na temelju te Istine adekvatan odgovor, koji mora biti plod poštivanja cjelokupnog kodeksa moralnih i etičkih vrijednosti upisanih u čovjekovu bogoliku narav. Temeljna ljudska prava, od kojih je prvo pravo na život od začeća do prirodne smrti, ključ je ostvarenja zajedništva, te slobode i demokracije. Samo veličina ponizne vjere u Isusa Krista, na koju poziva Papa, koja pruža svjedočanstvo ljubavi, spremnosti na odricanje i žrtvu, te strpljivosti koja čeka u nadi, u stanju je danas promijeniti smjer suvremenog društva prema smislu i istinskom napretku. Poslanje Crkve kao navjestiteljice Radosne vijesti i braniteljice života danas, dva desetljeća poslije, više nego ikad treba biti usmjereno obrani čovjeka te podršci mladima i obitelji - kućnoj Crkvi i izvoru života i radosti, a u cilju ostvarenja kulture života. Kao kreatori demokratizacije društva kršćani ne smiju danas stajati po strani, niti olako prelazit preko vlastitih uvjerenja poradi partikularnih interesa, već su pozvani ostvarivati društvo po mjeri čovjeka - hodočasnika Evanđelja. Preduvjet napretka i budućnosti jest nastavak istinskog liječenja rana i konačni obračun s povijesnom istinom, umjesto usko interesnog produbljivanja podjela, te razumijevanje, uzajamno praštanje i pomirba, koja će poštivati dostojanstvo i prava svakog čovjeka. Ostvarenjem tih egzistencijalnih vrijednosti u čijem središtu stoji Bog, sadašnjost se oslobađa veriga ranjene prošlosti, a budućnost po mjeri čovjeka biva ispunjena nadom, nasuprot suvremene proklamacije neoliberalnog ropstva i beznađa. 
Sasvim je sigurno da su Papine riječi i danas, dva desetljeća poslije, vrlo precizan kompas, koji se u proteklom razdoblju zapostavljalo u orijentaciji društva, a nerijetko i u mlakosti Crkve. Sveti je Papa u prijelomnom trenutku povijesti hrvatskog naroda, prosuđujući prošlost, sadašnjost i budućnost, priopćio konkretnu i uvijek aktualnu istinu. Slijedom navedenoga sve govore izrečene u prigodi ovog pastirskog pohoda, a osobito one izrečene u Splitu i Solinu, možemo smatrati trajnom poveljom o identitetu čovjeka, Crkve i društva te programom za ostvarenje sigurne sadašnjosti i budućnosti.

\section{MAN, CHURCH AND SOCIETY IN THE MESSAGES OF JOHN PAUL II IN SPLIT AND SOLIN 1998}

\section{Summary}

The author analyses the address of Pope John Paul II during the second pastoral visit to Croatia, with a special emphasis on the meetings in Split and Solin, wanting to find a foundation and the invaluable value in a 20-year time gap, for the Church and Croatian society in the turbulent times of today. The truth about man, the Church and society he warns about, is based on the evangelical treasure and historical experience; it has an impassable value and after two decades invites us for a pastoral and social inventory. In the centre of the Pope's attention is man with his identity and mission in the Church and in society. The Pope is rightly presenting himself as the pilgrim of the gospel because for him the gospel represents admiration over man's dignity in the light of the proclamation. Such illuminated identity and the associated witness testimony of man, the Church, and society are directed towards building a culture of life and preserving the same. Man is the starting, the central and the underlying point of evangelization and democratization processes. The imperative of today is the healing of historical wounds, so that man could, on the brink of the third millennium, remain opposed to the dangers of hedonism and consumerism on a solid foundation of Christian values that contribute to the true democratization of society.

Key words: John Paul II, man, pilgrimage, evangelization, democratization. 